\title{
Evaluation of serum LDH levels in the diagnosis and inmonitoring the response to the treatment in children with megaloblastic anaemia
}

\author{
Vinaya Kumar ${ }^{1}$, Mirji G. ${ }^{2}$ \\ ${ }^{1}$ Dr. Vinaya Kumar, Assistant Professor, ${ }^{2}$ Dr. Gangadhar Mirji, Assistant Professor; both authors are affiliated with \\ Department of Paediatrics, S.N. Medical College, Bagalkot, Karnataka, India.
}

Correspondence Author: Dr. Gangadhar Mirji, Assistant Professor, Department of Paediatrics, S.N. Medical College, Bagalkot, Karnataka, India. E-mail: drgangadharsm@gmail.com

\begin{abstract}
Background: Megaloblastic anaemia is still a common and preventable cause of anaemia in children.Invasive procedure like bone marrow examination and expensive investigation like estimation of serum vitamin B12 and folic acid levels are the definitive diagnostic tools. Their non availability at peripheral centre lead to a great deal of interest in other simple biochemical investigations like estimation of serum LDH levels. Design/methods: Children aged between 6 months to 14 yrs with clinically suspected megaloblastic anaemia formed the study group. A detailed clinical history and examination was done. All subjects had complete blood counts. Serum LDH levels, serum levels of vitamin B12 and folic acid levels were done. Serial measurements of serum LDH levels were done on day 14 and day 30 of treatment and were correlated with the haemoglobin and MCV levels. Results: A total of 48 patients formed the study group. All cases were anaemic with mean HB level of $5.25 \mathrm{~g} / \mathrm{dl}$, mean MCV was $100.15 \mathrm{fl}$. All cases had megaloblastic changes on peripheral smear.42 cases had low vitamin B12 levels and 6 cases had low folic acid levels. Serum LDH levels were elevated in all cases with mean level of $3423 \mathrm{IU} / \mathrm{L}$. There was a significant negative correlation between HB levels and serum LDH levels $(\mathrm{r}=-.923, \mathrm{p}<0.001)$ a significant positive correlation between MCV and serum LDH levels $(\mathrm{r}=$ $+0.810, \mathrm{p}<0.001$ ). One month after treatment HB levels and MCV improved (mean HB- $10.3 \mathrm{~g} / \mathrm{dl}$ and mean MCV$88.3 \mathrm{fl} / 1$ ). There was also a significantly fall in the serum levels of LDH 14 days and one month after treatment ( $\mathrm{p}<0.001$, $\mathrm{p}<0.001$ respectively). Conclusion: Serum LDH levelis an important investigation in the diagnosis and in monitoring the response to treatment in megaloblastic anaemia.
\end{abstract}

Keywords: Megaloblastic anemia, Serum LDH, Vitamin B12, Folic acid

\section{Introduction}

Megaloblastic anaemia constitutes a considerable health problem in developing countries like India. The incidence of megaloblastic anaemia in various part of our country is ranging from 3.1 to $71.1 \%$ [1].

Invasive procedure like bone marrow examination and expensive investigations like estimation of serum vitamin B12 and folic acid are the definitive diagnostic tools. Their non availability at peripheral centre lead to great deal of interest in other simple biochemical investigations like estimation of serum LDH levels. Elevation of plasma lactate dehydrogenase concentration (LDH) is known to occur in patients with megaloblastic anaemia. The literature on this subject is reviewed by Hess [2] and the value of LDH estimations

Manuscript received: $10^{\text {th }}$ May 2019

Reviewed: $20^{\text {th }}$ May 2019

Author Corrected: $25^{\text {th }}$ May 2019

Accepted for Publication: $30^{\text {th }}$ May 2019 as a screening test in the detection of megaloblastic anaemia is commented on by Fleming and Elliott [3]. Our studies were carried out to provide further information on LDH levels in megaloblastic anaemia and to evaluate the usefulness of serial estimations in assessing the response to physiological amounts of folic acid, and thus as a test of folic acid deficiency Since then number of workers documented the role of serum LDH in megaloblastic anemia. Serum LDH estimation can be used as a screening test for the diagnosis of megaloblastic anemia before performing a bone marrowaspiration [4].

\section{Objectives}

To evaluate the role of serum LDH level estimation in the diagnosis and in monitoring the response to treatment in children with megaloblastic anemia. 


\section{Materials and Methods}

Study type: Prospective study

Study period: June 2017 to May 20018

Inclusion criteria: Children aged between 6months and 14 yrs, clinically suspected of megaloblastic anemia.

Exclusion criteria: Those who were anaemic due to other causes.

This is a prospective study carried out in $\mathrm{S} N$ medical college between June 2017 and May 2018. Children
Original Research Article

aged between 6 months to 14 yrs with clinically suspected megaloblastic anaemia were selected. A detailed clinical history and thorough physical examination was done in all cases. All cases had complete blood counts, peripheral smear, serum LDH levels, serum levels of vitamin B12 and folic acid done. $\mathrm{CBC}$ and serum LDH levels were repeated at 14 days and 1 month after the treatment. Haemoglobin levels, and MCV were correlated with serum LDH levels before and after treatment. And serial measurements of LDH levels were used to monitor the response to the treatment. Ethical committee clearance was taken.

\section{Results}

A total of 48 cases were formed the study group. Mean age was 4.1 yrs, 28 were female and 20 were male. Mean haemoglobin level was $5.75 \mathrm{~g} / \mathrm{dl}$, mean MCV level was $100.12 \mathrm{fl}$, mean serum LDH level was 3423IU/L. Peripheral smear of all the cases had megaloblastic changes, 36 cases had macrocytic and 12 cases had dimorphic blood picture. 42 cases had low vitamin B12 levels and 6 cases had low folic acid levels.

Table-1: Mean Maximum and Minimum of different variables

\begin{tabular}{|c|c|c|}
\hline Parameter & Mean & Range (Minimum - Maximum) \\
\hline Age (yrs) & 4.19 & $0.5-14$ \\
\hline Hemoglobin (g/dl) & 5.725 & $2.7-9.6$ \\
\hline MCV (fl) & 100.15 & $88.2-112.1$ \\
\hline LDH level (IU/L) & 3423 & $1065-6678$ \\
\hline
\end{tabular}

There was a significant negative correlation between haemoglobin and serum LDH levels before and after treatment, and a significant positive correlation between MCV and serum LDH levels before and after treatment.

\section{Table-2: Correlation coefficients and their statistical significance}

There is a positive correlation between haemoglobin and serum LDH levels and a negative correlation between MCV and serum LDH levels.

\begin{tabular}{|c|c|c|}
\hline Correlation between & Before treatment & After treatment \\
\hline Hb v/s serum LDH & $\mathrm{r}--0.923, \mathrm{p}-<0.001$ & $\mathrm{r}--0.780, \mathrm{p}-<0.001$ \\
\hline $\mathrm{MCV}$ v/s serum LDH & $\mathrm{r}-+0.810, \mathrm{p}-<0.001$ & $\mathrm{r}-+0.843, \mathrm{p}-<0.001$ \\
\hline
\end{tabular}

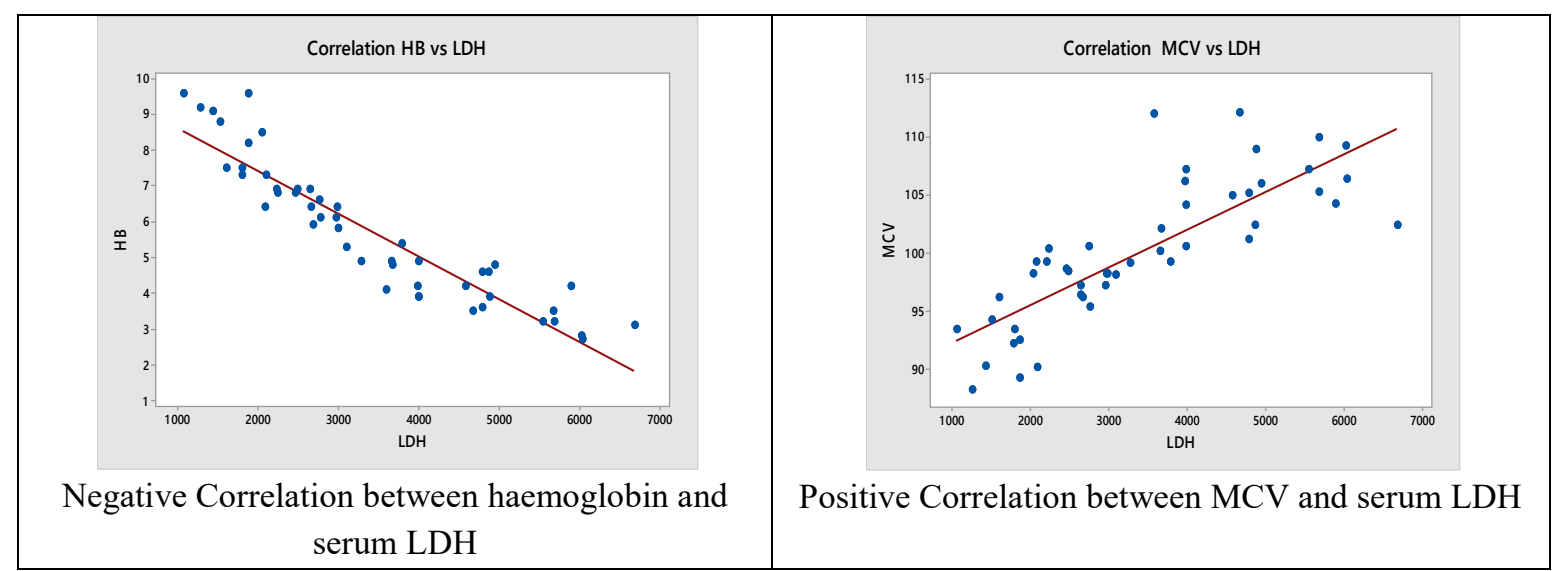

Figure-1: Scatter diagram showing the correlation between serum LDH and Hemoglobin levels and MCV 
There was a significant improvement in the haemoglobin level and MCV and a significant fall in the serum LDH levels at 14 days and 1 month after the treatment proven by the paired $\mathrm{T}$ test

Table-3: Comparison of mean levels of Hemogobin, MCV and LDH levels before and after treatment

\begin{tabular}{|c|c|c|}
\hline Haemoglobin & Mean (SD) g/dl & \\
\hline Before Rx & $5.725(1.929)$ & \multirow{2}{*}{$\mathrm{T}$ value $--26.47, \mathrm{p}-<0.001$} \\
\hline After Rx & $10.319(1.133)$ & \\
\hline MCV & Mean (SD) fl & \\
\hline Before Rx & $100.15(6.002)$ & \multirow{2}{*}{$\mathrm{T}$ value $--26.47, \mathrm{p}-<0.001$} \\
\hline After Rx & $88.19(4.366)$ & \\
\hline LDH levels & Mean (SD) IU/L & \\
\hline Before Rx & 3423 & \multirow{2}{*}{$\mathrm{T}$ value $-15.45, \mathrm{p}-<0.001$} \\
\hline After Rx & 681 & \\
\hline
\end{tabular}

Statistically significant improvement in the hemoglobin levels and MCV with treatment and significant fall in the serum LDH levels proven with paired T test.

Serial measurements of serum LDH levels showing fall in the levels with treatment (day 14 and one month)

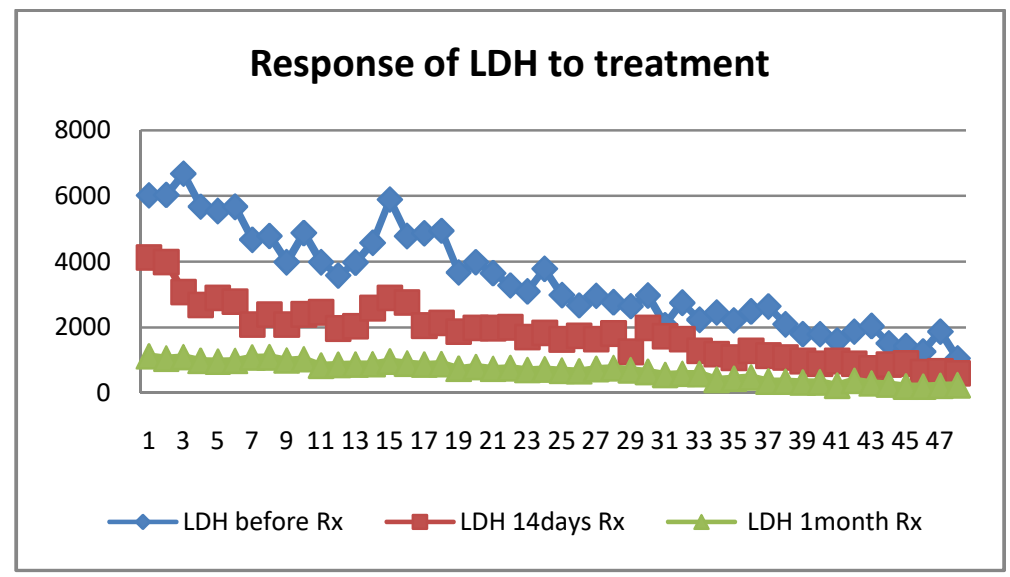

Figure-2: Response of serum LDH levels to treatment

\section{Discussion}

Megaloblastic anaemia is a significant cause of ill health in developing countries like India [1]. It is suggested that megaloblastic anaemia has been highly underestimated in our country and customary practice of treating anaemia with iron supplementation with subtherapeutic dosage of folic acid and Vit B12 may not provide the required correction of hemoglobin [5].

It is known that marked increase in serum LDH in megaloblastic anemia is due to intramedullary destruction of megaloblasts and high content of LDH in megaloblast.

Thus serum LDH can provide an important clue in the diagnosis of megaloblastic anemia. The present study was undertaken to highlight the serum LDH in diagnosis of megalolastic anaemia diagnosed on peripheral blood smear and bone marrow examination.
Mean age at diagnosis was $4.17 \mathrm{yrs}$, mean haemoglobin level was $5.85 \mathrm{~g} / \mathrm{dl}$, mean $\mathrm{MCV}$ was $100.1 \mathrm{fl}$ and mean LDH level was $3423 \mathrm{IU} / \mathrm{L}$. The maximum value of serum LDH was $8740 \mathrm{IU} / \mathrm{L}$ which was 30 times the normal value. Values as high as 28, 125 units/L have been reported and the serum $\mathrm{LDH}$ values reduced after treatment [6]. A correlation between reticulocytosis and decreasing $\mathrm{LDH}$ activity, followed later by rise in haemoglobin has been found in few studies $[7,8]$.

Correlation between serum LDH \& $\mathbf{H b}$ concentration: In megaloblastic anemia low value of hemoglobin is associated with disproportionally greater increase in total serum LDH level. In present study mean hemoglobin concentration was $5.85 \mathrm{gm} / \mathrm{dl} \pm 1.53$ gm/dl. Gronvell C et al (1961) [9] also found that there was an inverse relationship in megaloblastic anaemia i.e. low values $\mathrm{Hb}$ values are associated with disproportionately greater increase in serum LDH level. 
Prem Kumar M et al (2012) [10] in study showed mean $\mathrm{Hb}$ level in all patients was $5.3 \pm 1.69 / \mathrm{dl}$. Also showed inverse relationship. Gore et al (2015) [11] mean $\mathrm{Hb}$ in these study of 42 patients showed mean $\mathrm{Hb}$ as $5.41 \pm$ 1.11. Serum LDH was elevated in 38 patients $(90 \%)$ and showed inverse relationship between $\mathrm{LDH} \& \mathrm{Hb}$ value.

Serum LDH: In present study mean serum LDH was $3423 \mathrm{IU} / \mathrm{L}$. It means that, it was raised up to $10-20$ times the upper normal limit. Hess and Gehn (1955) [12] showed that LDH level raises 5-21 times than upper normal limit of serum LDH. With treatment there was a significant fall in the serum $\mathrm{LDH}$, which makes it a simple, cost effective serum marker in monitoring the treatment of megaloblastic anemia [12]

\section{Conclusion}

LDH levels in patients with megaloblastic anemia were raised above normal. Hence serum LDH might be used as a screening tool before doing any other diagnostic procedure and also there was a significant fall in the serum LDH levels with treatment. Thus we conclude that serum LDH may have an important role in diagnosis of megaloblastic anemia and also a cost effective tool in monitoring the response to treatment.

First and second author were major contributor in the collection of data, planning of study, and compilation of data.

What this study adds to existing knowledge: The present study recommends that in resource limited settings, serum LDH levels can add as a complimentary investigation to peripheral smear study in cases of megaloblastic anaemia and can be used a investigation tool in monitoring the response to the treatment

Funding: Nil, Conflict of Interest: None initiated Perission from IRB: Yes

\section{References}

1. Milman N. Anemia-still a major health problem in many parts of the world. Ann Hematol.2011;90(4): 369-77.
2. Hess B, Gehm E. Lactic acid dehydrogenase in the human blood. Klin Wochenschr. 1955; 33(3-4):91-3.

3. Elliott, B. A., and Fleming, A. F. Brit. med. J., 1, 626.Fleming, A. F., and Elliott, B. A. Ibid., 2, 1108.

4. Eivazi ZJ, Dastgiri S, Sanaat Z. Estimation of the diagnostic value of myeloperoxidase index and lactate dehydrogenase in megaloblastic anemia. J Clin Diag Res. 2007; 1(5):380-384.

5. Labhotia M, Shah P K D, Balani V, Gupta A, Saxena A, Sinha H V. Incidence of megaloblastic anemiain Indian adults and role of serum $\mathrm{LDH}$ as a diagnostic tool. Indian Journal of Haematology\& Blood Transfusion.1994; 12: 113-115.

6. Goldfarb TG, Papp BJ. Excessively high levels of lactic acid dehydrogenase activity in pernicious anemia. Am J Med. 1963; 34:578-622.

7. Gordin R, Eanri TM. Lactic dehydrogenase in vitamin B12 deficiency. Acta Hematol. 1959; 21(1):16-22.

8. Emerson PM, Wilkinson JH. Lactate dehydrogenase in the diagnosis and assessment of response to treatment of megaloblastic anemia. Brit J Hematol. 1966; 12(6): 678-87.

9. GronvallC.; On the serum activity.of lactic acid dehydrogenase and phosphohexose isomerase in pernicious and haemolytic anemia, Scand. Journal of Clinical Pathology and LabInvestigation.1961; 1329-60.

10. Premkumar M, N. Gupta, T. Singh, and T. Velpandian. Cobalamin and Folic Acid Status in Relation to the Etiopathogenesis of Pancytopenia in Adults at a Tertiary Care Centre in North India.2012.

11. Gore B.P, Kurundkar G, Bhat S. Retrospective Study of Serum LDH in Megaloblastic Anemia. Indian Journal of Applied Research. 2015; 5:454-55.

12. Winston RM, Warburton FG, Stott A. Enzymatic diagnosis of megaloblastic anemia. $\mathrm{Br} \mathrm{J}$ Haematol. $1970 ; 19$ (5):587-92.

\section{How to cite this article?}

Vinaya Kumar, Mirji G. Evaluation of serum LDH levels in the diagnosis and inmonitoring the response to the treatment in children with megaloblastic anaemia. Int J Pediatr Res. 2019;6 (05):217-220.doi:10.17511/ijpr.2019.i05.04 